\title{
Major tectonic units of the North China Craton and their Paleoproterozoic assembly
}

\author{
ZHAO Guochun (赵国春) ${ }^{1}$, SUN Min (孙 敏) ${ }^{1} \&$ Simon A. Wilde ${ }^{2}$ \\ 1. Department of Earth Sciences, the University of Hong Kong, Pokfulam Road, Hong Kong, China; \\ 2. School of Applied Geology, Curtin University of Technology, GPO Box U1987, Perth, W.A. 6845, Australia \\ Correspondence should be addressed to Zhao Guochun (email: gzhao@hkucc.hku.hk)
}

Received February 14, 2002

\begin{abstract}
The basement of the North China Craton can be divided into the Eastern and Western Blocks and the Central Zone (Trans-North China Orogen). The West Block formed by the amalgamation of the Ordos Block in the south and the Yinshan Block in the north 1.9-2.0 Ga ago. In 1.8-1.9 Ga, the Eastern and Western Blocks were amalgamated along the Central Zone to form the North China Craton.
\end{abstract}

Keywords: North China Craton, collision tectonics, Paleoproterozoic.

In the last decade, Chinese geologists have made a remarkable progress in studies on the lithology, structural style, metamorphic evolution, geochemistry and geochronology of the North China Craton, including recognition of numerous tonalitic-trondhjemitic-granodioritic (TTG) plutons ${ }^{[1-3]}$, fragments of ancient oceanic crust ${ }^{[4-6]}$, high-pressure granulites and retrograded eclogites ${ }^{[7,8]}$, crustal-scale ductile shear zones and domes ${ }^{[2,3,9,10]}$, near-isobaric cooling anticlockwise and near-isothermal decompression clockwise P-T paths ${ }^{[11-15]}$, and $3.8-3.9$ Ga metasedimentary and granitoid rocks ${ }^{[16]}$. These new advances have led to a reevaluation of the basement tectonic units of the craton and their tectonic evolution, as embodied in a number of new proposals on the tectonic division of the craton ${ }^{[1-3,10,17-19]}$. Of these new proposals, however, the metamorphic evolution of different terrains in the craton has not fully been taken into account. Much of the recent research in metamorphic petrology has shown that modern field- and thermodynamics-based metamorphic investigations, in combination with lithological, structural and geochronological considerations, can be directed towards understanding of tectonic setting and processes that were operative during the metamorphic event. For example, clockwise, especially isothermal decompressional, P-T-t paths are considered to be related to continent-continent collision environments ${ }^{[20]}$, whereas anticlockwise, especially isobaric cooling, P-T-t paths are related to the intrusion and underplating of mantle magmas, which can occur in continental magmatic arc regions, hot spots related to mantle plumes and rift environments ${ }^{[21]}$. However, these new advances on the relationships between metamorphic evolution and tectonic setting have not been reflected in the present proposals of the tectonic division of the North China Craton.

Recently, we have summarized the major differences of metamorphic P-T paths between the 
Eastern and Western Blocks and the Central Zone of the North China Craton, and along with lithological, structural, geochemical and geochronological considerations, we have for the first time proposed that the basement of the craton can be divided into the Eastern and Western Blocks, separated by a Central Zone (fig. 1), along which the Eastern and Western Blocks were amalgamated to form the North China Craton at $\sim 1.85 \mathrm{Ga}^{[22-26]}$. On the basis of these studies, this paper integrates new geological and geochronological data to further characterize these major tectonic units and expound the tectonic processes of their Paleoproterozoic amalgamation to form the North China Craton.

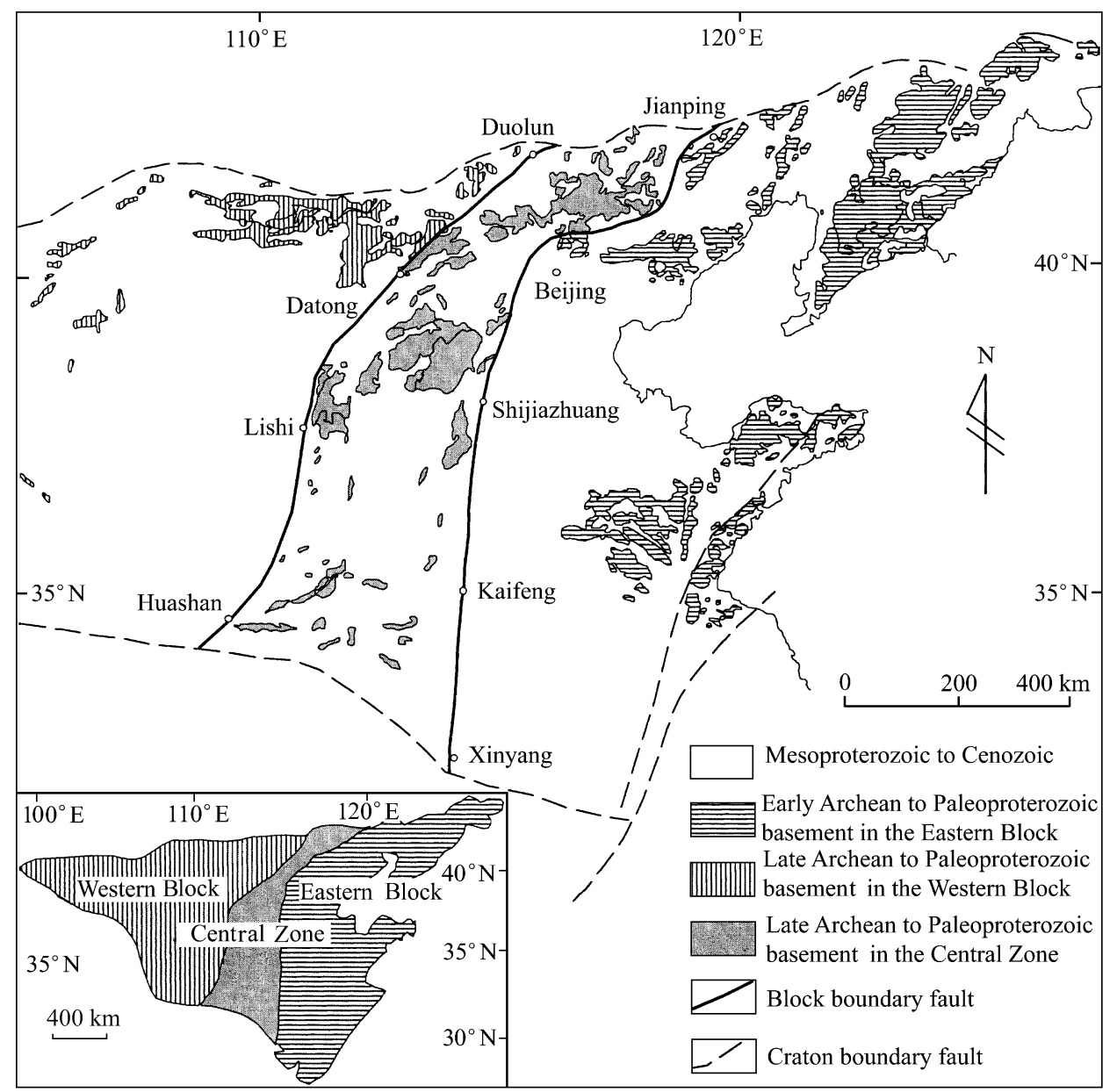

Fig. 1. Spatial distribution of the basement rocks and tectonic division of the North China Craton.

\section{Eastern Block}

The basement rocks of the Eastern Block are exposed as high-grade terrains or low-grade granite-greenstone belts in Southern Jilin, North Liaoning, Anshan-Benxi, Southern Liaoning, Western Liaoning, Eastern Hebei, Miyun, Western Shandong and Eastern Shandong. They are 
dominated by a late Archean lithological assemblage, with minor early to middle Archean rocks, including 3.3-3.8 Ga granitic gneisses and $3.85 \mathrm{Ga}$ fuchsite-bearing quartzites in local areas. The late Archean basement rocks consist predominantly of $2.8-2.5 \mathrm{Ga}$ tonalitic-trondhjemitic-granodioritic (TTG) gneisses, ultramafic to mafic igneous intrusives and dykes and minor amounts of supracrustal rocks. Of these rocks, TTG gneisses make up $70 \%$ of the total exposure of the late Archean basement ${ }^{[2,3]}$; ultramafic rocks have affinities to peridotitic and komatiitic rocks $^{[27]}$; and the supracrustal rocks comprise sedimentary and bimodal volcanic rocks ${ }^{[22]}$. All these rocks were regionally deformed and metamorphosed from greenschist to granulite facies during $2.48-2.50 \mathrm{Ga}^{[2,3]}$, which resulted in the formation of syntectonic charnockites in high-grade terrains and granites in granite-greenstone belts. The early-to-middle Archean rocks have been found only in the Anshan and Eastern Hebei areas, including 3.6-3.9 Ga detrital zircons-bearing fuchsite-bearing quartzites and $\sim 3.5 \mathrm{Ga}$ amphibolites in the Caozhuang area of Eastern Hebei and the 3.3-3.8 Ga granitoids and metasedimentary rocks in the Anshan area ${ }^{[16]}$. These early to middle Archean rocks may have experienced multiple episodes of metamorphism and deformation between $3.8 \mathrm{Ga}$ and $2.5 \mathrm{Ga}$, but much of their petrographic and isotopic information on the early tectonothermal events has been obliterated by the last metamorphic event at $\sim 2.5 \mathrm{Ga}$. Therefore, it remains unknown regarding the tectonic setting, spatial distribution and tectonic evolution of these rocks. The Paleoproterozoic rocks mainly crop out in the Liaoning and Shandong regions, represented by the Liaohe, Jingshan and Fenzishan groups and associated Paleoproterozoic granites ${ }^{[28,29]}$, which are considered to have formed in an intra-continental rift environment $^{[29]}$.

Structurally, TTG gneiss domes, separated by linear belts of supracrustal rocks, dominate the late Archean basement in the Eastern Block. The domes are generally circular, elliptical or oval in plane, $10-50 \mathrm{~km}$ in diameter, and consist of broadly uniform TTG gneisses, locally associated with $\sim 2.5 \mathrm{Ga}$ syntectonic granites in the cores of the domes. The representative domes include the Qianan, Chuizhangzi and Taipingzhai-Santunying domes in Eastern Hebei, Qingyuan Dome in Northern Liaoning, Huadian Dome in Southern Jilin, Jinzhou Dome in Southern Liaoning, etc. Controversy has surrounded the origins of these domes, with one school of thought believing that they resulted from the superimposition of multiple folds ${ }^{[30]}$, whereas others argue that they were related to the diapiric intrusion of granitoid magmas ${ }^{[22]}$.

The metamorphic evolution of the late Archean basement rocks of the Eastern Block, regardless of high-grade terrains or low-grade granite-greenstone belts, is characterized by anticlockwise P-T paths involving near-isobaric cooling (fig. 2(a)). Mafic granulites, amphibolites and pelitic gneisses in the Eastern Block preserve prograde, peak and post-peak mineral assemblages. The prograde assemblage is indicated by inclusions within minerals of the peak stage, represented by the assemblages of hornblende + plagioclase + quartz \pm biotite in mafic granulites, chlorite + actinolite + epidote + plagioclase + quartz in amphibolites and biotite + plagioclase + quartz \pm an- 


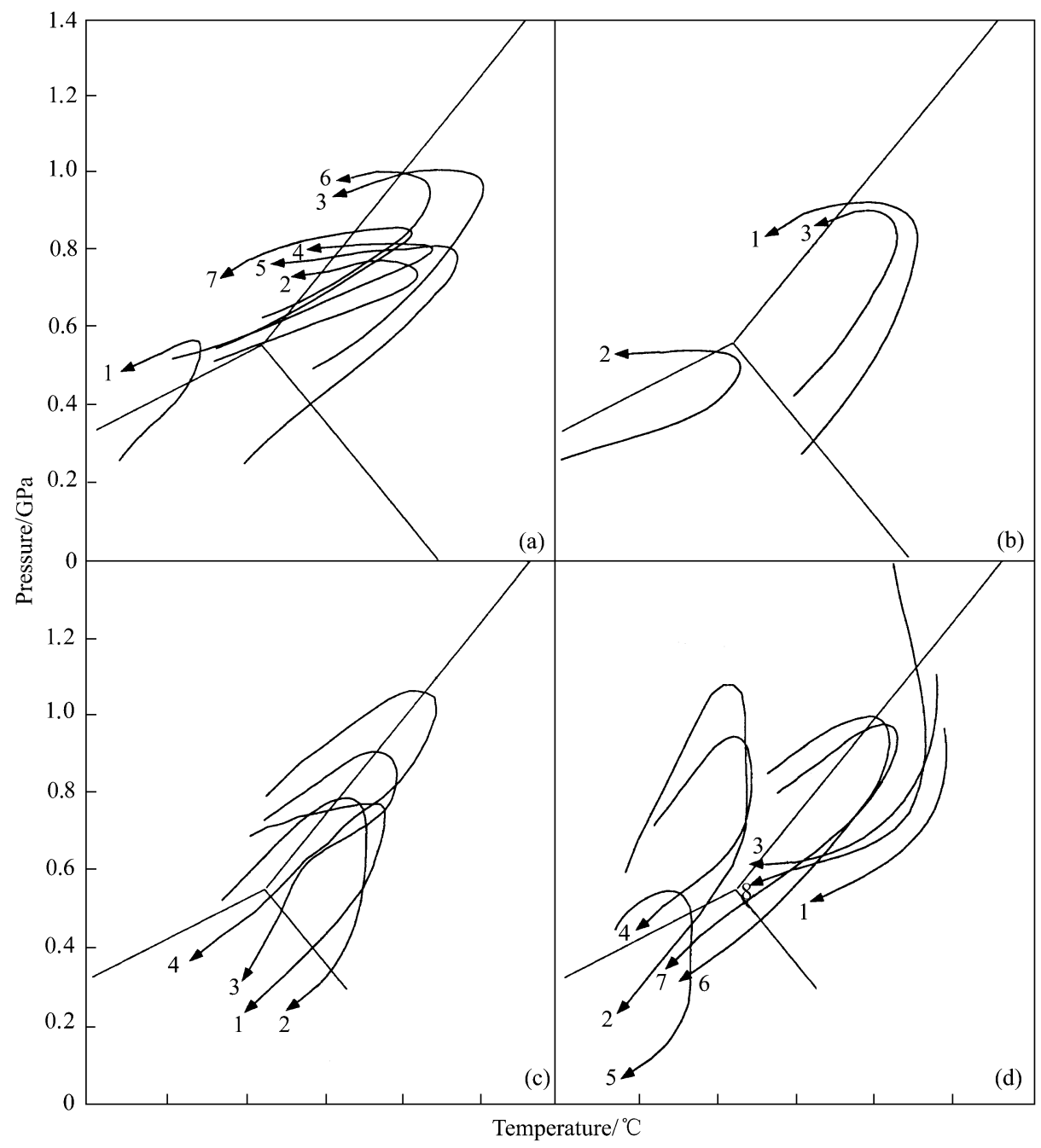

Fig. 2. Metamorphic P-T paths of the basement rocks of the North China Craton.

dalusite in pelitic gneisses (e.g. the presence of relict andalusites within planar sillimanite crystals from the Caozhuang pelitic gneiss, Eastern Hebei ${ }^{[22]}$ ). The peak assemblage is shown by the assemblages of orthopyroxene + clinopyroxene + garnet + plagioclase + quartz in mafic granulites, hornblende + plagioclase + quartz + garnet in garnetiferous amphibolites and garnet + sillimanite + plagioclase + quartz + biotite in pelitic gneisses. The post-peak assemblage is characterized by garnet + quartz symplectic coronas in mafic granulites (fig. 3(a)), actinolite + garnet retrogressive rims around garnet or hornblende grains in amphibolites, and kyanite replacing sillimanite or staurolite replacing sillimanite + garnet in pelitic gneisses ${ }^{[22]}$. These mineral assemblages and their P-T estimates define nearly isobaric cooling, anticlockwise, P-T paths, reflecting an origin related to the intrusion and underplating of large amounts of mantle-derived magmas ${ }^{[31]}$. 

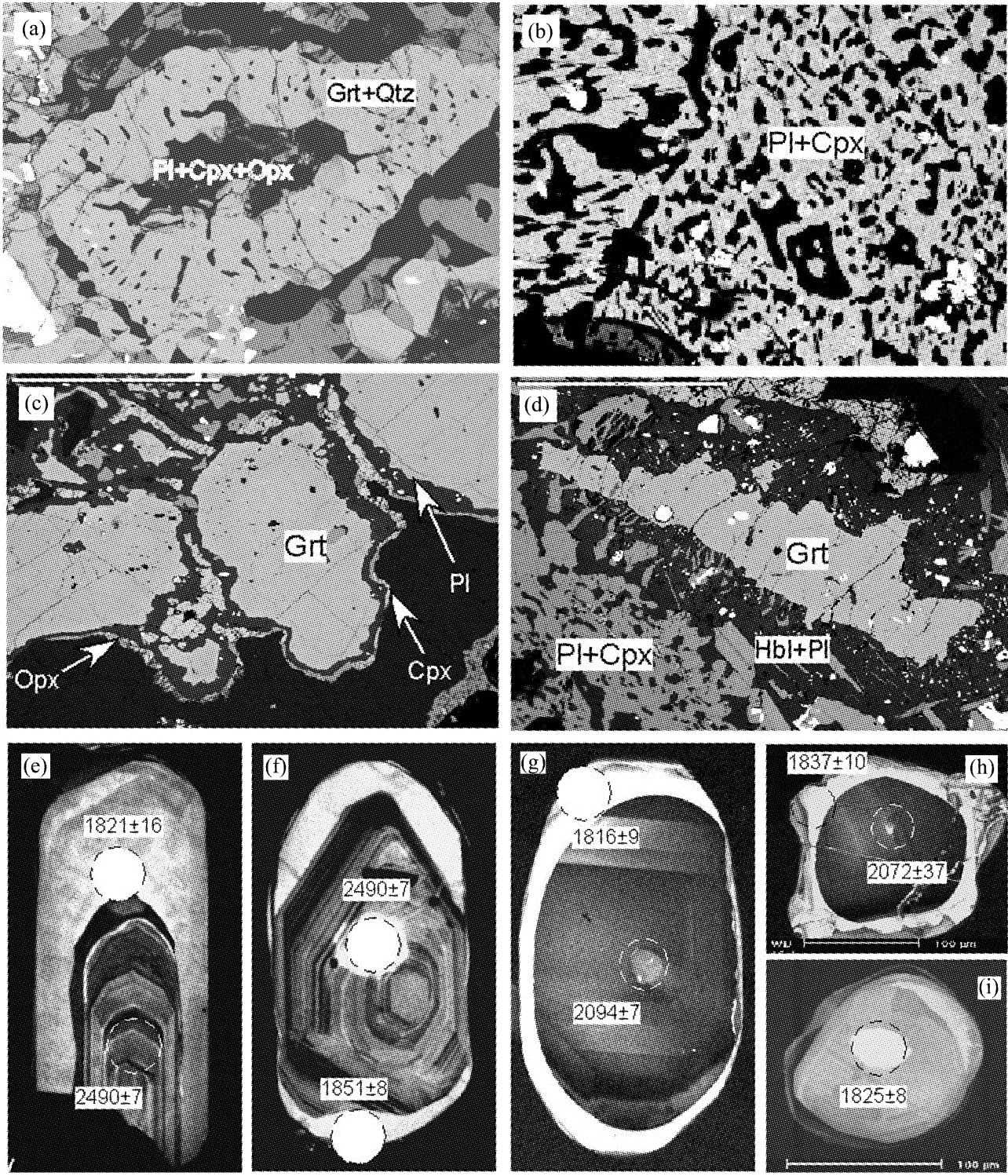

Fig. 3. Back-scattered electron (BSE) images showing representative metamorphic textures and cathodoluminescence (CL) images showing internal structures of zircons from the Fuping Complex. (a) Garnet + quartz symplectites surrounding plagioclase + pyroxene in mafic granulites from Eastern Hebei; (b) Na-rich plagioclase + clinopyroxene symplectite formed by the breakdown of omphacites; (c) pyroxene + plagioclase coronas surrounding embayed garnet grains in the Hengshan mafic granulites; (d) hornblende + plagioclase symplectite on embayed garnet grains in the Hengshan mafic granulites; (e) and (f) metamorphic zircons occurring as overgrowth rims surrounding the magmatic zircon cores in the Archean Fuping tonalitic gneisses; (g) and (h) metamorphic zircons occurring as overgrowth rims surrounding the magmatic zircon cores in the Paleoproterozoic Fuping granitic gneisses; (i) metamorphic zircons occurring as single grains in the Archean Fuping tonalitic gneisses. Age unit in (e) - (i) is million years (Ma). Mineral symbols are after the result of R. Kreze: Symbols for rock-forming minerals, American Mineralogist, 1983, 68: 277-279. 


\section{Western Block}

The basement rocks in the Western Block are mainly exposed in the northern part of the block, especially in the Jining, Daqingshan-Ulashan, Guyang-Wuchuan, Sheerteng, Helanshan-Qianlishan, and Alashan areas, whereas the southern part of the block is covered with the Ordos basin. Data from sporadic drillings reveal the existence of the late Archean granulite-facies basement beneath the Ordos basin ${ }^{[32]}$, and some aeromagnetic data also imply the existence of granulite-facies basement beneath the Donghongsheng area ${ }^{[3]}$. The exposed basement can be further divided into two distinct lithotectonic units: the late Archean TTG + supracrustals and the Paleoproterozoic Khondalite Belt. The former crops out as granite-greenstone or high-grade terrains in the Guyang, Wuchuan, Sheerteng and Alashan areas in the northern part of the block, whereas the latter is exposed as a typical linear structural belt along the Jining-Daqingshan-Ulashan-Qianlishan-Helanshan zone, separating the northern late Archean basement from the Ordos basin.

The late Archean basement of the Western Block has a lithological assemblage, structural style and metamorphic history similar to those of the Eastern Block, comprising TTG gneiss complexes associated with minor supracrustal rocks (including sedimentary rocks and bimodal volcanic rocks). These rocks underwent a greenschist to granulite facies metamorphic event at $\sim 2.5$ $\mathrm{Ga}$, in association with the formation of syntectonic charnockites and granites. Moreover, the metamorphic evolution of these late Archean basement rocks from both high-grade terrains and low-grade granite-greenstone belts is characterized by anticlockwise P-T paths involving near-isobaric cooling ${ }^{[11,13]}$. For instance, like those in the Eastern Block, mafic granulites in the Guyang and Wuchuan areas also contain the prograde assemblage of hornblende + plagioclase + quartz \pm biotite as inclusions within garnet and pyroxene grains, peak assemblage of orthopyroxene + clinopyroxene + garnet + plagioclase \pm quartz as a porphyroblast or matrix, and post-peak assemblage of garnet + quartz as symplectic coronas. These mineral assemblages and their P-T estimates define a nearly isobaric, anticlockwise, P-T path (fig. 2(b)), which suggests that the metamorphic event was related to the intrusion and underplating of mantle-derived magmas ${ }^{[23]}$.

The Paleoproterozoic Khondalite Belt consists of khondalite series, TTG gneiss with minor mafic granulites, and syntectonic charnockites and S-type granites. The khondalite series is composed of graphite-bearing sillimanite-garnet gneisses, garnet quartzites, calc-silicate rocks and marbles, which generally are considered to represent stable continental margin deposits ${ }^{[33]}$. It has long been accepted that the khondalite series in the Western Block formed in the Archean ${ }^{[34]}$, since in most cases it occurs in a close association with the Archean TTG gneisses and mafic granulites. However, this notion has never been supported by the available isotopic data, which suggest that the khondalite series formed in the Paleoproterozoic, with depositional ages ranging from 2.3 to $1.9 \mathrm{Ga}$ and a metamorphic age of $1.9-1.8 \mathrm{Ga}^{[35-38]}$.

Graphite-bearing pelitic gneiss from the khondalite series preserves four distinct mineral as- 
semblages (M1-M4). M1 is represented by mineral inclusions within the M2 garnet porphyroblasts and consists of plagioclase + biotite + quartz \pm kyanite \pm rutile; M2 represents the growth of garnet porphyroblasts and matrix plagioclase + biotite + quartz + sillimanite \pm ilmenite; M3 is represented by cordierite coronas and cordierite + orthopyroxene or cordierite + spinel symplectites, surrounding garnet porphyroblasts; and M4 represents retrograde minerals biotite + chlorite replacing garnets, K-feldspar + sericite + chlorite replacing cordierites and andalusite + muscovite cutting the regional foliation. These mineral assemblages and their thermobarometric estimates define clockwise P-T paths involving near-isothermal decompression (fig. 2(c)), reflecting a continent-continent collision environment.

We previously interpreted the clockwise P-T paths of the Khondalite Belt as having resulted from the Paleoproterozoic collision between the Eastern and Western Blocks ${ }^{[23,25]}$. However, this interpretation cannot well explain the formation of the khondalites occurring far away from the Central Zone, such as those in the Daqingshan, Ulashan, Qianlishan and Helanshan areas. Therefore, we propose in this paper that the Khondalite Belt may represent a Paleoproterozoic collision belt, along which the Yinshan Block represented by the late Archean basement in the north and the Ordos Block in the south were amalgamated to form the Western Block in the Paleoproterozoic (fig. 4). This scenario can well explain the spatial distribution of the Khondalite Belt in the Western Block. As most khondalites occur surrounding the borderlands of the Ordos basin, it is reasonably inferred that the khondalite series may represent stable continental margin deposits of the Ordos Block. The TTG gneisses and mafic granulites coexisting with the khondalites cannot be assigned to the formation of stable continental margin deposits; they may represent a continental magmatic arc or island arc bordering the southern margin of the Yinshan Block. The Paleoproterozoic collision between the Yinshan and Ordos Blocks resulted in a spatial mixture of the

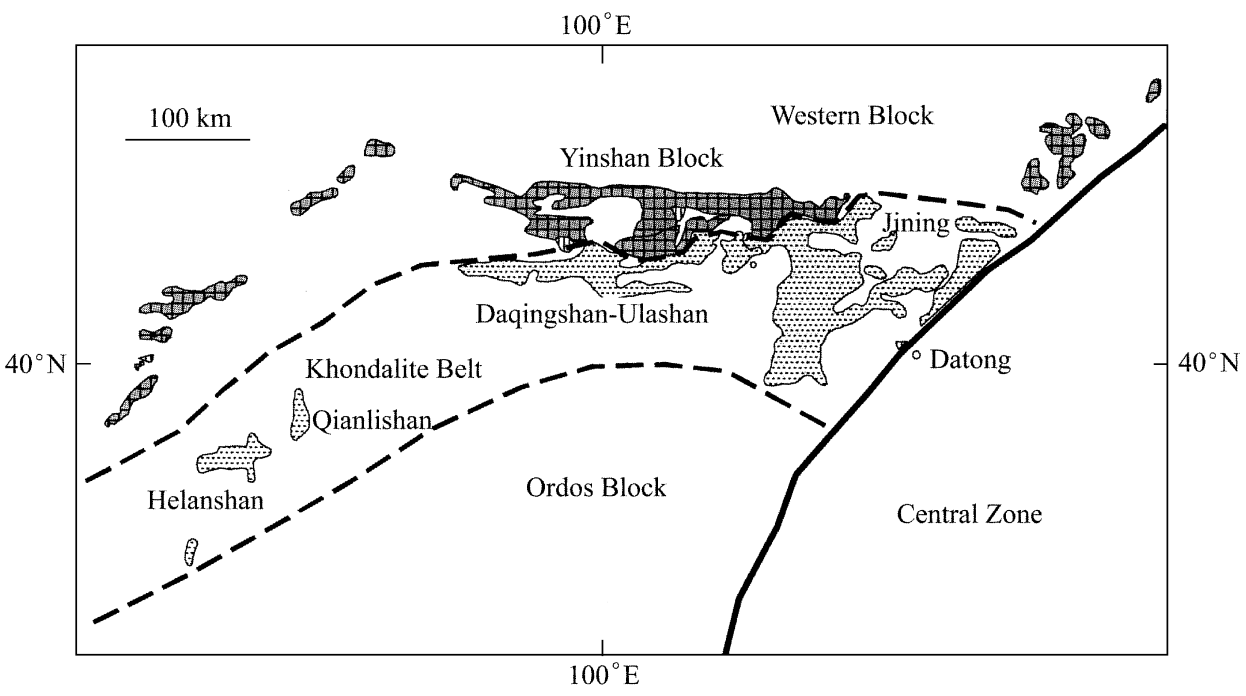

Fig. 4. Spatial distribution of the Khondalite Belt, Ordos Block and Yinshan Block in the Western Block. 
khondalite series and the TTG gneisses and mafic granulites, forming the Paleoproterozoic Khondalite Belt. The collision between the Yinshan and Ordos Blocks must have occurred earlier than the collision between the Eastern and Western Blocks, which resulted in the formation of the Central Zone. The available data indicate that the khondalites from the Jining Complex near the junction of the Khondalite Belt and the Central Zone underwent two high-grade metamorphic events $^{[33]}$. Moreover, there may have existed a temperature-lowering period between the two high-grade metamorphic events because some biotite crystals, which formed from the retrograde breakdown of garnet porphyroblasts during the first metamorphic event, were transferred to fibrous sillimanites during the second metamorphic event by the following reaction:

$$
\begin{gathered}
4 \mathrm{~K}(\mathrm{Mg}, \mathrm{Fe})_{3}\left(\mathrm{AlSi}_{3}\right) \mathrm{O}_{10}(\mathrm{OH})_{2}(\text { biotite }) \rightarrow 2 \mathrm{Al}_{2} \mathrm{SiO}_{5} \text { ( sillimanite) }+10 \mathrm{SiO}_{2} \text { (quartz) } \\
+12(\mathrm{Mg}, \mathrm{Fe}) \mathrm{O}+2 \mathrm{~K}_{2} \mathrm{O}+4 \mathrm{H}_{2} \mathrm{O}^{[33]}
\end{gathered}
$$

This implies that these two high-grade metamorphic events may represent two independent tectonothermal events. Metamorphic reaction textures and thermobarometric estimates show that a clockwise P-T path involving nearly isothermal decompression characterizes the metamorphic evolution of both the high-grade events. This suggests that the khondalites near the junction of the Khondalite Belt and the Central Zone encountered two collision events. In contrast, the khondalites from those areas far away from the Central Zone (e.g. those in Daqingshan, Ulashan, Qianlishan, Helanshan, etc.) only experienced one high-grade metamorphic event, which further supports the conclusion that the metamorphism of the Khondalite Belt occurred earlier than that of the Central Zone.

\section{Central Zone}

The Central Zone is separated from the Western Block by the Huashan-Lishi-Datong-Duolun (HLDD) Fault and from the Eastern Block by the Xingyang-Kaifeng-Shijiazhuang-Jianping (XKSJ) Fault (fig. 1). Both faults strike N-S in the central and southern parts and turn to N-E in the north (fig. 1). The central and southern segments of the XKSJ Fault are also called the Zhuoxian-Shijiazhuang Fault and Xingtai-Anyang Fault and constitute part of a major fault system in the eastern part of China ${ }^{[39]}$. The presence of voluminous mantle-derived basalts exposed along the two faults suggests that these faults are deep-seated, possibly reaching into the lower crust or upper mantle ${ }^{[39]}$. Because of the lack of reliable geochronological data, whether these two faults represent the original fundamental boundaries between the two blocks and the Central Zone remains unknown.

The basement rocks of the Central Zone are mainly exposed in the Chengde, Dengfeng, Fuping, Hengshan, Huai'an, Lüliang, Taihua, Wutai, Xuanhua, Zanhuang and Zhongtiao areas, and consist of late Archean to Paleoproterozoic TTG gneisses, supracrustal rocks (metamorphosed sedimentary and volcanic rocks), mafic dykes, and syn- or post-syntectonic granites. Geochemical data suggest that much of the basement formed in continental magmatic arc, island arc or back-arc basin environments ${ }^{[40,41]}$. Minor ultramafic to mafic rocks have been interpreted to be fragments 
of ancient oceanic crust, the prime example of which is the metamorphosed peridotitegabbro-diabase-pillow lava assemblage in the Jingangku Formation of the Wutai Group ${ }^{[4-6]}$. Compared with the late Archean basement of the Eastern Block, the basement of the Central Zone contains a higher proportion of supracrustals, of which marbles and calc-silicate rocks rarely occur in the late Archean basement of the Eastern Block. The TTG gneisses and supracrustals of the Central Zone underwent a multiple deformation and were metamorphosed from greenschist to granulite facies, and thus the basement of the Central Zone can be further subdivided into high-grade terrains and low-grade granite-greenstone belts. The former includes the Taihua, Fuping, Hengshan, Huai' an, Xuanhua and Chengde complexes, whereas the latter includes the Dengfeng, Zhongtiao, Zanhuang, Lüliang, Wutai and Northern Hebei complexes. TTG gneisses and supracrustal rocks in the high-grade terrains have long been considered to be Archean in age, but new isotopic data reveal that some of them may have formed in the Paleoproterozoic. For example, most recent SHIRMP zircon U-Pb analyses have shown that some of protolith rocks of granitic gneisses from the Fuping Complex formed at $\sim 2.0 \mathrm{Ga}^{[42,43]}$, whereas the sillimanite gneiss from the Wanzi supracrustal rocks of the Fuping Complex has the maximum depositional age of 2.1 $\mathrm{Ga}^{[43,44]}$. Nd isotopic data suggest that no significant amounts of the basement older than $2.6 \mathrm{Ga}$ exist in the Central Zone ${ }^{[41]}$, although minor amounts of the $2.7 \mathrm{Ga}$ basement rocks may have existed in some local areas ${ }^{[43,44]}$; they may represent the fragments of the reworked Archean crust forming at some time prior to the formation of magmatic arcs and back-arc basins that were subsequently incorporated into the Central Zone.

The structural style of the late Archean to Paleoproterozoic basement rocks in the Central Zone is characterized by linear belts which are primarily outlined by a number of NNE-SSW trending ductile shear zones, in which mineral lineations are ubiquitous and locally there are sheath folds, which indicate a broadly eastward thrusting ${ }^{[10]}$. In some areas (e.g. Fuping, Dengfeng, etc.), small-scale gneiss domes occur, with their long axes parallel to the regional foliation; they are interpreted to have resulted from a fold superimposition ${ }^{[45,46]}$. Recent geological investigations reveal a high-pressure granulite-retrograded eclogite belt ${ }^{[7,8,47]}$, which occur along a northeastsouthwest trending zone that extends from the Hengshan area, through the Huai' an and Xuanhua, into Chengde, with a distance of $\sim 500$ kilometers ${ }^{[47]}$. The southern part of the Central Zone is occupied by a high-pressure amphibolite belt along which occur $(10-14) \times 10^{8}$ Pa garnet amphibolites and kyanite-staurolite-anthophyllite mafic schist ${ }^{[48,49]}$. This high-pressure amphibolite belt seems to be the tectonic counterpart of the high-pressure granulite belt, and they together constitute a large-scale Paleoproterozoic high-pressure belt that traverses the Central Zone and represents an important terrane boundary.

The basement rocks of the Central Zone preserve the peak, post-peak decompression and later cooling mineral assemblages ${ }^{[46,47,49,50]}$. The representative peak assemblages, which occur as porphyroblasts or matrix minerals, include garnet + quartz + omphacite pseudomorph (clinopyroxene + Na-rich plagioclase) in retrograded eclogites, garnet + quartz + plagioclase + clinopy- 
roxene in high-pressure granulites, garnet + quartz + plagioclase + clinopyroxene + orthopyroxene in medium-pressure granulites, garnet + hornblende + plagioclase + quartz \pm rutile in amphibolites, and garnet + plagioclase + K-feldspar + quartz + biotite + sillimanite/kyanite in medium-pressure pelitic gneisses. The post-peak decompressional assemblages occur as coronas or symplectites surrounding the peak minerals. In retrograded eclogites, the decompression assemblage is represented by symplectite clinopyroxene + Na-rich plagioclase (fig. 3(b)), which has been found in many other retrograded eclogite terrains and is considered to have formed from the breakdown of omphacite during the transformation of eclogites to high-pressure granulites ${ }^{[51]}$. In high- and medium-pressure granulites, the decompression assemblage is represented by symplectite orthopyroxene + Ca-rich plagioclase or corona orthopyroxene + clinopyroxene + Ca-rich plagioclase surrounding the embayed garnet grains (fig. 3(c)). In amphibolites, the decompression assemblage is the hornblende/cummingtonite + plagioclase symplectite surrounding the embayed garnet grains, and in pelitic gneisses, the decompression assemblage is represented by cordierite coronas or cordierite + orthopyroxene/spinel symplectites. The later cooling assemblages include the hornblende + plagioclase symplectite in high- and medium-pressure granulites, chlorite + biotite replacing garnet in amphibolites, and biotite + K-feldspar \pm muscovite replacing cordierite, garnet or sillimanite in pelitic gneisses. These mineral assemblages and their thermobarometric estimates define a clockwise P-T path involving near-isothermal decompression and cooling following the peak metamorphism (fig. 2(d)), suggesting a continent-continent collision environment for the Central Zone.

\section{Timing of amalgamation of the Eastern and Western blocks}

The high-grade gneisses, low- to medium-grade granite-greenstone terrains and very low-grade metavolcanic and metasedimentary rocks in the Central Zone have long been assigned to the products of three different tectonothermal events, named the Fuping ( 2.5 Ga), Wutai (2.4 $-2.3 \mathrm{Ga})$ and Lüliang ( 1.8 Ga) "movements", respectively ${ }^{[39]}$. This was built up on a few "unconformities", conventional multigrain U-Pb zircon geochronology, and a misconception that high-grade metamorphic rocks were older than low-grade ones. However, a recent study has shown that the so-called "unconformities" between these "movements" are regional-scale ductile shear zones ${ }^{[9]}$. Moreover, recent geochronological data do not support the existence of the Fuping and Wutai "movements" in the Central Zone. In the Fuping, Wutai and Hengshan areas, for example, SHRIMP U-Pb zircon ages reveal that the high-grade Fuping and Hengshan gneiss complexes are not older than the low-grade Wutai granite-greenstone terrain (table 1); they are all characterized by the emplacement of major granitoid bodies between 2.55 and $2.45 \mathrm{Ga}$, deposition of supracrustal rocks from late Archean to Paleoproterozoic Era, and intrusion of granitic bodies at 2.2 -2.0 Ga (table 1). SHRIMP U-Pb zircons studies combined with cathodoluminescence images and U-Th chemistry confirm the existence of only one phase of metamorphic zircons in nearly all medium- to high-grade lithologies from these complexes ${ }^{[43]}$. These metamorphic zircons occur as 
either overgrowth rims surrounding older magmatic zircon cores (fig. $3\left(\mathrm{e}^{-\mathrm{h}}\right)$ ) or single grains (fig. 3(i)), and are structureless, highly luminescent and very low in Th and U contents. These features make them distinctly different from the magmatic zircons that are generally characterized by oscillatory zoning, low luminescence and comparatively high Th and U contents. The metamorphic zircons from different rocks of the Fuping and Hengshan Complexes yield similar concordant ${ }^{207} \mathrm{~Pb} /{ }^{206} \mathrm{~Pb}$ ages in the range from 1870 to $1800 \mathrm{Ma}$ (table 1 ), which are $700 \mathrm{Ma}$ to 150 Ma younger than their magmatic zircon cores. A conclusion from these data is that the main regional metamorphism of the basement rocks in the Central Zone occurred at $\sim 1.85 \mathrm{Ga}$ (Lüliang "movement"), not at the end of the Archean, as previously considered by most Chinese geologists. This conclusion is consistent with recent isotopic data obtained by using other dating methods. These include a garnet-clinopyroxene-orthopyroxene Sm-Nd isochron age of (1824 \pm 18$)$ Ma and a U-Pb zircon age of $(1833 \pm 23)$ Ma from high-pressure granulites in the Huai' an Complex ${ }^{[53]}$, a hornblende Ar/Ar age of $(1781 \pm 20)$ Ma from the Jingangku amphibolites of the Wutai Group ${ }^{[6]}$, a

Table 1 SHRIMP zircon U-Pb ages for Hengshan, Wutai and Fuping Complexes

\begin{tabular}{|c|c|c|c|c|}
\hline Rock type & Age /Ma & Zircon type & Age interpretation & Sources $^{\mathrm{a}}$ \\
\hline \multicolumn{5}{|l|}{ Hengshan Complex } \\
\hline \multirow{2}{*}{ Tonalitic gneiss } & $2520 \pm 15$ & magmatic core & crystallization age & \multirow[b]{2}{*}{ (1) } \\
\hline & $1872 \pm 17$ & metamorphic rim & metamorphic age & \\
\hline \multirow{2}{*}{ Garnet quartzite } & $2527 \pm 10$ & detrital zircon & age of source rock & \multirow[b]{2}{*}{ (1) } \\
\hline & $1872 \pm 17$ & metamorphic rim & metamorphic age & \\
\hline Mafic granulite & $1827 \pm 10$ & metamorphic zircon & metamorphic age & (1) \\
\hline \multicolumn{5}{|l|}{ Wutai Complex } \\
\hline Granitic gneiss & $2546 \pm 3$ & magmatic zircon & crystallization age & (2) \\
\hline Granitic gneiss & $2531 \pm 5$ & magmatic zircon & crystallization age & (2) \\
\hline Granitic gneiss & $2520 \pm 9$ & magmatic zircon & crystallization age & (2) \\
\hline Metadacite & $2533 \pm 8$ & magmatic zircon & protolith age & (2) \\
\hline Metadacite & $2524 \pm 8$ & magmatic zircon & protolith age & (2) \\
\hline Subvolcanics & $2516 \pm 8$ & magmatic zircon & protolith age & (2) \\
\hline Monzogranite & $2117 \pm 18$ & magmatic zircon & crystallization age & (2) \\
\hline Porphyric granite & $2176 \pm 12$ & magmatic zircon & crystallization age & (2) \\
\hline Porphyric granite & $2107 \pm 15$ & magmatic zircon & crystallization age & (2) \\
\hline \multicolumn{5}{|l|}{ Fuping Complex } \\
\hline \multirow{2}{*}{ Tonalitic gneiss } & $2514 \pm 11$ & magmatic core & crystallization age & \multirow{2}{*}{ (3) } \\
\hline & $1805 \pm 48$ & metamorphic rim & metamorphic age & \\
\hline \multirow{2}{*}{ Trondhjemitic gneiss } & $2499 \pm 6$ & magmatic core & crystallization age & \multirow{2}{*}{ (3) } \\
\hline & $1861 \pm 20$ & metamorphic rim & metamorphic age & \\
\hline \multirow{2}{*}{ Granodioritic gneiss } & $2485 \pm 9$ & magmatic core & crystallization age & \multirow{2}{*}{ (3) } \\
\hline & $1824 \pm 9$ & metamorphic rim & metamorphic age & \\
\hline \multirow{2}{*}{ Monzogranitic gneiss } & $2084 \pm 12$ & magmatic core & crystallization age & \multirow{2}{*}{ (3) } \\
\hline & $1826 \pm 18$ & metamorphic rim & metamorphic age & \\
\hline \multirow{2}{*}{ Granodioritic gneiss } & $2023 \pm 24$ & magmatic core & crystallization age & \multirow[t]{2}{*}{ (3) } \\
\hline & $1850 \pm 11$ & metamorphic rim & metamorphic age & \\
\hline
\end{tabular}

a) (1), From S. A. Wilde, SHRIMP zircon U-Pb ages of the Hengshan Complex, ARC Project Report (unpublished data); (2) from Wilde et al. (1997) ${ }^{[52]}$; (3) from Zhao et al. $(2001)^{[43]}$. 
zircon U-Pb lower intercept age of $(1817 \pm 17) \mathrm{Ma}$ and a metamorphic zircon U-Pb age of $(1831 \pm 4)$ Ma from high-pressure granulites in the Chengde Complex, a zircon U-Pb upper intercept age of (1800 \pm 7$)$ Ma from the Luyashan charnockite in the Lüliang Complex ${ }^{[54]}$, a SHRIMP metamorphic zircon $\mathrm{U}-\mathrm{Pb}$ age of $(1833 \pm 53) \mathrm{Ma}$ from the Wanzi pelitic gneiss of the Fuping Complex $^{[55]}$, garnet-whole Sm-Nd ages of $(1842 \pm 38)$ Ma from the Xiwangshan high-pressure granulites and $(1856 \pm 26)$ Ma from the Cicheng high-pressure amphibolites in the Xuanhua Complex ${ }^{[56]}$, and a garnet Ar/Ar age of $(1852 \pm 8)$ Ma from the Xiwangshan high-pressure granulites in the Xuanhua Complex ${ }^{[57]}$. All these data indicate that the collision between the Eastern and Western Blocks occurred in the range of $\sim 1.85-1.80 \mathrm{Ga}$.

\section{Assembly of the North China Craton}

As discussed above, distinct differences in lithology, structural style, metamorphic evolution and geochronology exist between the eastern, central and western parts of the North China Craton. This implies that the North China Craton had no uniform basement in the late Archean. The available data suggest that during the late Archean to Paleoproterozoic, the North China Craton consisted of three different cratonic blocks: Eastern Block, Yinshan Block and Ordos Block. The Yinshan and Eastern blocks have similar late Archaean lithotectonic assemblages, structural styles and metamorphic P-T paths. They are both composed of 2.6-2.5 Ga TTG gneisses, ultramafic (komatiitic) to mafic igneous rocks, $\sim 2.5 \mathrm{Ga}$ syntectonic granites, with minor amounts of $2.55-2.50 \mathrm{Ga}$ supracrustal rocks. All these rocks underwent regional metamorphism at $\sim 2.5 \mathrm{Ga}$, shortly after their formation. The regional metamorphism is characterized exclusively by IBC-type anticlockwise P-T paths, and the structural style is dominated by TTG gneiss domes separated by linear belts of supracrustal rocks. These features do not support a continent-continent collision model for the formation of the basement rocks in the Yinshan and Eastern blocks. The possible tectonic environments include continental magmatic arc regions, hot spots driven by mantle plumes, or continental rift regions. Based on a number of factors such as the existence of a $\sim 800$ $\mathrm{km}$ wide and similar-aged igneous belt, large voluminous komatiitic rocks and bimodal volcanics, widespread domiform structures and near-isobaric cooling anticlockwise P-T paths, we favour a mantle plume model to interpret the formation of the basement rocks in the Yinshan and Eastern blocks $^{[22,25,31]}$.

The lithological compositions and tectonic nature of the Ordos Block remain unknown due to a thick cover of sediments. However, widespread presence of Paleoproterozoic khondalites on the periphery of the Ordos Block suggests that the block had a stable and passive continental margin environment during the Paleoproterozoic. In contrast, the Yinshan Block had an active-type continental margin environment (continental magmatic arc or island arc), in which TTG plutons and mafic to felsic volcanics formed during the late Archean to Paleoproterozoic. During 2.0 - 1.9 $\mathrm{Ga}$, the northern margin of the Ordos Block was amalgamated to the southern margin of the Yinshan Block, leading to the formation of the Khondalite Belt. The precise timing and detailed tec- 
tonic process of the collision between the Yinshan and Ordos blocks need further investigations.

In the late Archean to Paleoproterozoic Era, the Eastern Block was separated from the Yinshan and Ordos blocks and the later Western Block by an ancient ocean. The oceanic crust was subducted beneath the western margin of the Eastern Block, leading to the formation of continen-

Western Block

Passive-type continental margin

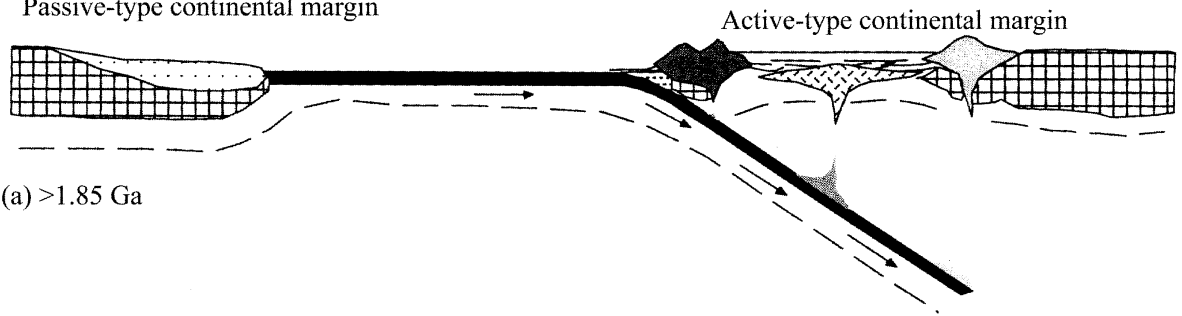

Western Block

(b) $\sim 1.85 \mathrm{Ga}$

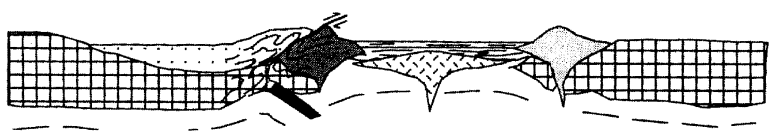

(c) $1.85-1.80 \mathrm{Ga}$

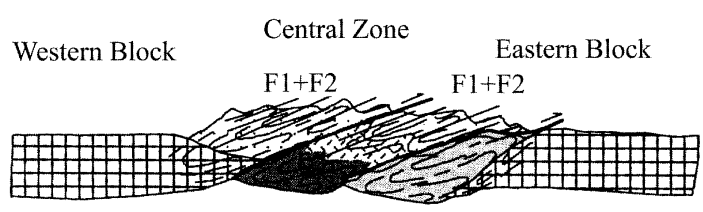

(d) $1.85-1.80 \mathrm{Ga}$

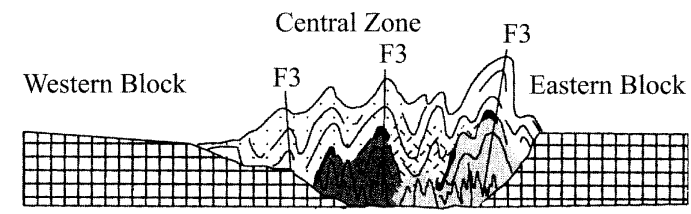

Central Zone

Western Block

Eastern Block

(e) $<1.80 \mathrm{Ga}$

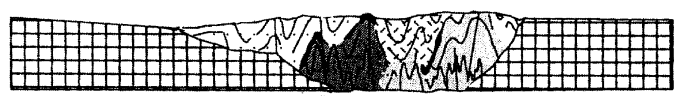

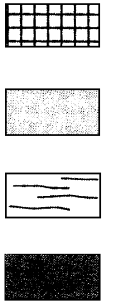

Archean continental basement in the Eastern and Western blocks

Late Archean to Paleoproterozoic remnant magmatic arc formation

Late Archean to Paleoproterozoic sediments in back-arc basins

Late Archean to Paleoproterozoic continental magmatic arc formation

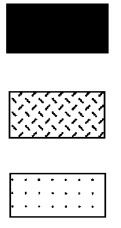

Late Archean to Paleoproterozoic oceanic crust

Late Archean to Paleoproterozoic volcanic formation in intra-arc basins

Paleoproterozoic sediments on passive continental margins

Folds related to the collision between the Eastern and Western blocks

Fig. 5. A model for the Paleoproterozoic evolution of the North China Craton. 
tal margin magmatic arcs, island arcs and back-arc basins that were subsequently incorporated into the Central Zone (fig. 5(a)). At $\sim 1.85 \mathrm{Ga}$, the ocean between the two blocks was completely consumed through subduction, and collision between the Eastern and Western blocks occurred (fig. 5(b)). The collision caused crustal-scale folding, thrusting and thickening, and resulted in medium- to high-pressure granulite facies or eclogite facies metamorphism in the lower crust and greenschist to amphibolite facies metamorphism in the upper crust (fig. 5(c)). Following the peak metamorphism, the thickened crust underwent exhumation and accompanying decompression, which resulted in the development of asymmetric folds and widespread symplectic textures in the rocks (fig. (d)). Finally, retrogressive metamorphism took place when the crust was exhumed to shallow levels (fig. 5(e)). These tectonic processes led to the final assembly of the North China Craton at $\sim 1.80 \mathrm{Ga}$.

Acknowledgements Zhao Guochun is indebted to an anonymous reviewer and the executive editor for their constructive comments and helps. This work was supported by an RGC Grant of Hong Kong, China (Grant Nos. HKU7115/00P and HKU7090/01P)

\section{References}

1. Deng, J. F., Wu, Z. X., Zhao, G. C. et al., Precambrian granitic rocks, continental crustal evolution and craton formation of the North China Platform, Acta Petrologica Sinica (in Chinese with English abstract), 1999, 15(2): 190-198.

2. Bai, J., Dai, F. Y., Archean crust of China, in Precambrian Crust Evolution of China (eds. Ma, X. Y., Bai, J.), Beijing: Springer Geological Publishing House, 1998, 15-86.

3. Wu, J. S., Geng, Y. S., Shen, Q. H. et al., Archean Geological Characteristics and Tectonic Evolution of China-Korea Paleo-continent (in Chinese), Beijing: Geological Publishing House, 1998, 1-212.

4. Li, J. L., Wang, K. Y., Wang, C. Q. et al., Early Proterozoic collision orogenic belt in the Wutaishan area, China, Scientia Geologica Sinica (in Chinese with English abstract), 1990, 25, 1-11.

5. Bai, J., Wang, R. Z., Guo, J. J., The Major Geologic Events of Early Precambrian and Their Dating in Wutaishan Region (in Chinese with English abstract), Beijing: Geological Publishing House, 1992, 1—55.

6. Wang, K. Y., Li, J. L., Hao, J. et al., Late Archaean mafic-ultramafic rocks from the Wutaishan, Shanxi Province: A possible ophiolite mélange, Acta Petrologica Sinica (in Chinese with English abstract), 1997, 13, 139—151.

7. Zhai, M. G., Guo, J. H., Yan, Y. H., Discovery and preliminary study of the Archean high-pressure granulites in North China, Science in China, Ser. B, 1993, 36(11): 1402-1408.

8. Zhai, M. G., Guo, J. H., Li, J. H. et al., Retrograded eclogites in the Archean North China Craton and their geological implications, Chinese Science Bulletin, 1996, 41(4): 315-320.

9. Li, J. H., Qian, X. L., A study on Longquanguan shear zone in northern part of the Taihang Mountains, Shanxi Geology (in Chinese), 1991, 6(1): 17-29.

10. Wu, C. H., Li, H. M., Zhong, C. T. et al., The ages of zircons and rutiles from khondalite in the Huangtuyao area, Inner Mongolia, Geology Review (in Chinese), 1998, 21(3): 28-50.

11. Jin, W., Li, S. X., Liu, X. S., The Metamorphic dynamics of Early Precambrian high-grade metamorphic rocks series in the Daqing-Ulashan area, Inner Monglia, Acta Petrologica Sinica (in Chinese with English abstract), 1991, 7(4): 27 -35.

12. Lu, L. Z., Metamorphic P-T-t path of the Archean granulite-facies terrains in Jining area, Inner Mongolia and its tectonic implications, Acta Petrologica Sinica (in Chinese with English Abstract), 1991, 7(4): 1-12.

13. Liu, X. S., Jin, W., Li, S. X. et al., Two types of Precambrian high-grade metamorphism, Inner Mongolia, China, Journal of Metamorphic Geology, 1993, 11: 499-510.

14. Liu, S. W., P-T path of granulites in the Fuping area, Geological Journal of Chinese Universities (in Chinese), 1996, 2(1): $75-84$. 
15. Liu, F. L., Metamorphic reactions and mineral evolution of garnet mafic granulites in the Manjinggou area, Journal of Changchun University of Sciences and Technology (in Chinese), 1998, 28(1): 16-22.

16. Liu, D. Y., Nutman, A. P., Compston, W. et al., Remnants of 3800 crust in the Chinese Part of the Sino-Korean craton, Geology, 1992, 20: 339-342.

17. Shen, Q. H., Qian, X. L., Archean rock assemblages, episodes and tectonic evolution of China, Acta Geoscientia Sinica (in Chinese with English abstract), 1995, 2: 113-120.

18. Li, J. H., Qian, X. L., Zhai, M. G., The tectonic division of the North China granulite facies belt and its early Precambrian tectonic evolution, Scientia Geologica Sinica (in Chinese), 1997, 32(3): 254-265.

19. Zhai, M. G., Bian, A. G., Zhai, T. P., The amalgamation of the supercontinent of North China Craton at the end of Neo-Archean and its break-up during late Paleoproterozoic and Mesoproterozoic, Science in China, Ser. D, 2000, 43(Suppl.): 219-232.

20. Brown, M., P-T-t evolution of orogenic belts and the causes of regional metamorphism, Journal of Geological Society, London, 1993, 150: 227-241.

21. Bohlen, S. R., On the formation of granulites, Journal of Metamorphic Geology, 1991, 9: 223-229.

22. Zhao, G. C., Wilde, S. A., Cawood, P. A. et al., Thermal evolution of Archean basement rocks from the eastern part of the North China Craton and its bearing on tectonic setting, International Geology Review, 1998, 40: 706-721.

23. Zhao, G. C., Wilde, S. A., Cawood, P. A. et al., Tectonothermal history of the basement rocks in the western zone of the North China Craton and its tectonic implications, Tectonophysics, 1999, 310: 37-53.

24. Zhao, G. C., Cawood, P. A., Wilde, S. A. et al., Metamorphism of basement rocks in the Central Zone of the North China Craton: Implications for Paleoproterozoic tectonic evolution, Precambrian Research, 2000, 103: 55-88.

25. Zhao, G. C., Wilde, S. A., Cawood, P. A. et al., Archean blocks and their boundaries in the North China Craton: Lithological, geochemical, structural and P-T path constraints and tectonic evolution, Precambrian Research, 2001, 107: 45-73.

26. Zhao, G. C., Paleoproterozoic assembly of the North China Craton, Geological Magazine, 2001, 138: 87-91.

27. Zhang, Y. X., Yan, H. Q., Wang, K. D. et al., Komatiites from the Qianxi Group in the eastern Hebei Province, China, Journal of Changchun University of Sciences and Technology (in Chinese), 1980, 10(1): 1—8.

28. Sun, M., Armstrong, R. L., Lambert, R. St. J. et al., Petrochemistry and Sr, Pb, and Nd isotopic geochemistry of early Proterozoic Kuandian Complex, eastern Liaoning Province, China, Precambrian Research, 1993, 63: 171—190.

29. Li, S. Z., Yang, Z. S., Paleoproterozoic tectonic framework of the eastern part of the North China Platform, Journal of Changchun University of Sciences and Technology (in Chinese), 1995, 25(1): 14-21.

30. Bai, Y. L., On the ancient folds in the eastern Hebei Province, Geological Research (in Chinese), 1980, 3(1): 68 - 90.

31. Zhao, G. C., Wilde, S. A., Cawood, P. A. et al., Thermal evolution of two textural types of mafic granulites in the North China Craton: Evidence for both mantle plume and collisional tectonics, Geological Magazine, 1999, 136: 223 - 240.

32. Wu, C. H., Li, S. X., Gao, J. F. et al., Archean and Paleoproterozoic metamorphic regions in the North China Craton, in Metamorphism and Crustal Evolution of China (ed. Dong, S. B.) (in Chinese), Beijing: Geological Publishing House, 1986, 53-89.

33. Lu, L. Z., Jin, S. Q., Xu, X. T. et al., Petrogenesis and Mineralization of Khondalite Series in the Southeastern Inner Mongolia (in Chinese), Changchun: Jilin Science \& Technology Press, 1992, 47-118.

34. Qian, X. L., Li, J. H., The discovery of Neoarchean unconformity and its implication for continental cratonization of the North China Craton, Science in China, Ser. D, 1999, 42(4): 401—407.

35. Wu, C. H., Li, H. M., Zhong, C. T. et al., The ages of zircons and rutiles from khondalite in the Huangtuyao area, Inner Mongolia, Geological Review (in Chinese), 1998, 44(6): 618-626.

36. Wang, J., Lu, S. N., Li, H. M. et al., Geochronological framework of metamorphic rocks in the middle part of Inner Mongolia, Bulletin of Tianjin Institute of Geology \& Mineral Resources (in Chinese), 1995, 29: 1-76.

37. Wan, Y. S., Geng, Y. S., Shen, Q. H. et al., Khondalite series-geochronology and geochemistry of the Jiehekou Group in the Lüliang area, Shanxi Province, Acta Petrologica Sinica (in Chinese), 2000, 16(1): 49—58. 
38. Geng, Y. S., Wan, Y. S., Shen, Q. H. et al., Early Precambrian geological events and geochronological framework of the Lüliang area, Acta Geologica Sinica (in Chinese), 2000, 74(3): 216-223.

39. Ren, J. S., Jiang, C. F., Zhang, Z. K. et al., Geotectonic Evolution of China, Berlin: Springer-Verlag, $1987,1-203$.

40. Geng, Y. S., Wu, J. S., Geochemistry and evolution of the early Precambrian mafic rocks in the Wutai-Taihangshan area, Special Publication of Precambrian Geology (in Chinese), 1990, 4: 167-174.

41. Sun, M., Armstrong, R. L., Lambert, R. St. J., Petrochemistry and Sr, Pb and Nd isotopic geochemistry of Early Precambrian rocks, Wutaishan and Taihangshan areas, China, Precambrian Research, 1992, 56: 1-31.

42. Liu, S. W., Liang, H. H., Zhao, G. C., et al., Isotopic chronology and geological events of Precambrian complex in Taihangshan region, Science in China, Ser. D, 2000, 43(4): 386-393.

43. Zhao, G. C., Wilde, S. A., Cawood, P. A. et al., SHRIMP U-Pb zircon ages of the Fuping Complex: Implications for accretion and assembly of the North China Craton, American Journal of Science, 2002, 302: 196-221.

44. Guan, H., Sun, M., Wilde, S. A. et al., SHRIMP U-Pb zircon geochronology of the Fuping Complex: Implications for formation and assembly of the North China Craton, Precambrian Research, 2001, 113: 1-18.

45. Zhang, S. G., Jin, L. G., Xiao, Q. H., Structural styles and deformational history of Archean composite folds in the Fuping Complex, Regional Geology of China (in Chinese), 1983, 2(6): 336-347.

46. Zhao, G. C., Wilde, S. A., Cawood, P. A. et al., Petrology and P-T path of the Fuping mafic granulites: Implications for tectonic evolution of the central zone of the North China Craton, Journal of Metamorphic Geol., 2000, 18: 375-391.

47. Zhao, G. C., Wilde, S. A., Cawood, P. A. et al., High-pressure granulites (retrograded eclogites) from the Hengshan Complex, North China Craton: Petrology and tectonic implications, Journal of Petrology, 2001, 42: 1141—1170.

48. Wang, K. Y., Hao, J., Cawood, P. et al., High-pressure metamorphism in kyanite-bearing schists from the original Jingangku Formation of the Wutaishan, Precambrian Geology and Metamorphic Petrology, 1997, 17: 213 - 220.

49. Zhao, G. C., Cawood, P. A., Lu, L. Z., Petrology and P-T history of the Wutai amphibolites: Implications for tectonic evolution of the Wutai Complex, China, Precambrian Research, 1999, 93: 181-199.

50. Zhao, G. C., Cawood, P. A., Wilde, S. A. et al., Polymetamorphism of Archean mafic granulites from the Trans-North China Orogen: Textural and thermobarometric evidence and tectonic implications, in Continental Reworking and Reactivation (Eds. Miller, J., Buick, I. S.), Geological Society Special Publication, London: the Geological Society, 2001, 184: 323-342.

51. Rubie, D. C., Role of kinetics in the formation and preservation of eclogites, in Eclogite Facies Rocks (ed. Carswell, D. A.), London: Blackie, 1990, 111-140.

52. Wilde, S. A., Cawood, P. A., Wang, K. Y., The relationship and timing of granitoid evolution with respect to felsic volcanism in the Wutai Complex, North China Craton, Precambrian Geology and Metamorphic Petrology, 1997, 17: 75—88.

53. Guo, J. H., Zhai, M. G., Zhang, Y. G., Early Precambrian Manjinggou high-pressure granulites melange belt on the southern edge of the Huaian Complex, North China Craton: Geological features, petrology and isotopic geochronology, Acta Petrologica Sinica (in Chinese with English abstract), 1993, 9: 329-341.

54. Mao, D. B., Zhong, C. T., Chen, Z. H. et al., Isotopic ages and geological implications of high-pressure mafic granulites in the northern Chengde area, Hebei Province, Acta Petrologica Sinica (in Chinese with English abstract), 1999, 15, 524534.

55. Wu, C. H., Li, H. M., Zhong, C. T. et al., Single zircon U-Pb ages of the Fuping and Wanzi gneisses: Geochronological evidence for non-uniform Archean basement of the Fuping Complex, Progress in Precambrian Research (in Chinese), 2000, 23(3): 129-139.

56. Guo, J. H., Zhai, M. G., Sm-Nd age dating of high-pressure granulites and amphibolites from Sanggan area, North China Craton, Chinese Science Bulletin, 2001, 46: 106-111.

57. Guo, J. H., Wang, S. S., Liang, H. Q. et al., $\mathrm{Ar}^{40} / \mathrm{Ar}^{39}$ age spectra of garnet porphyroblast: Implications for metamorphic age of high-pressure granulite in the North China craton., Acta Petrologica Sinica (in Chinese with English abstract), 2001, 17(3): $436-442$. 